\title{
Association between Foxp3 Tumor Infiltrating Lymphocyte Expression and Response After Chemoradiation in Nasopharyngeal Carcinoma
}

\author{
Lisnawati Lisnawati, Yayi Dwina Billianti, Amelia Fossetta Manatar* \\ Department of Anatomical Pathology, Faculty of Medicine, University of Indonesia, Dr. Cipto Mangunkusumo National General \\ Hospital, Jakarta, Indonesia
}

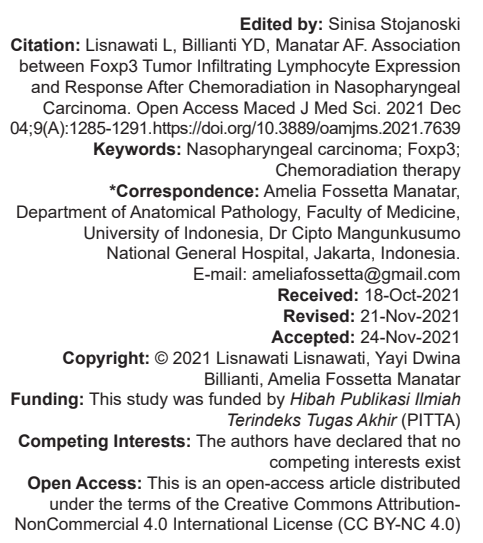

Introduction

Nasopharyngeal carcinoma (NPC) is a carcinoma originating from the surface epithelium of the nasopharynx with the highest incidence in China and South East Asia. The incidence of NPC varies according to geography. The highest incidence rate in the world is in Southeast China, which is $40-50$ cases of nasopharyngeal cancer among 100.000 people, but it is very rare in Europe and North America with an incidence of around $1 / 100.000$ population. NPC is still a health problem in Indonesia and it is the $4^{\text {th }}$ most common malignancy after breast cancer, cervical cancer, and lung cancer [1], [2], [3], [4], [5].

The prognosis of NPC is reported to be poor related to the less than optimal management of NPC because in general (60-95\%) patients are treated at an advanced stage. The management of NPC refers to the National Guidelines for Handling Nasopharyngeal Cancer Medicine which includes a combination of chemotherapy and radiotherapy. Chemoresistance and recurrence to radiotherapy after 5 years are reported to reach $19-56 \%$ [5].
Various therapeutic responses to NPC make molecular research develop further and advanced. One of these molecular mechanisms is tumor microenvironment (TME) which can be assessed through lymphocyte infiltration around tumor cells/ tumor-infiltrating lymphocyte (TIL). Currently, TIL assessment is one of the strategies for the development of therapy through immunotherapy [6], [7].

Several studies have stated that TIL as a prognostic factor in NPC still shows varying results [7], [8]. TIL reflects the host's immune response to tumor cells. TIL as one of the TMEs consists of cytotoxic CD8 T lymphocytes, CD4.

Helper cells and Tregulators (Treg). Forkhead box protein P3 (Foxp3) is a specific Treg marker that plays a role in immunosuppression of the immune response to eliminate tumor cells [8], [9].

Foxp3 which regulates the development and function of Treg cells is currently known as the best marker for Tregs [10]. Tregs are against tumors through the inactivation of CD8 and CD4 T cells [11]. The relationship between Foxp3 expression and the response to NPC therapy can be considered as one 
of the factors that influence the prognosis as in a study conducted by Zhang et al. [9] It is known that CD8 lymphocyte cells are the most sensitive cells to radiation-induced apoptosis, whereas Treg cells are more resistant to radiation so that it has an impact on the microtumor environment that affects the response to therapy [12]. This study aims to determine the relationship between Foxp3 expression and treatment response in NPC.

\section{Materials and Methods}

This study is an observational analytic with a cross-sectional design. The study was conducted at the Department of Anatomical Pathology, Faculty of Medicine, Universitas Indonesia/Cipto Mangunkusumo Hospital. This study has passed ethical clearance from the Faculty of Medicine, Universitas Indonesia ethical committee. The study recruited 60 patients who were diagnosed and received chemoradiation therapy for NPC during the period between January 2018 to December 2020. Patients with stage II-IV who have complete clinical data and have been declared to have completed a series of therapy, both chemotherapy and/or external radiation, and have been evaluated for post-chemoradiation therapy by radiological examinations (magnetic resonance imaging or computed tomography scan of the nasopharynx) within a period of 8-12 weeks after therapy.

The evaluation of post-chemoradiation therapy response using RECIST which is divided into four types of response: complete response (CR), partial response (PR), progressive response (PD), and stable disease (SD). Patients with $\mathrm{CR}$ and $\mathrm{PR}$ were included in the response group, while patients with $P D$ and SD were included in the unresponsive group.

The examination was performed by the same pathologist. Five micron-sized sections taken from the selected blocks were placed onto slide coated by poly $\mathrm{L}$ lysine and then heated on a hot plate at $55-80^{\circ} \mathrm{C}$. Deparaffinized using xylol and rehydration with serial alcohol.

Then followed by heat-induced antigen retrieval using $0.1 \mathrm{M} \mathrm{NaOH}$ citrate buffer $(\mathrm{pH} 7.0)$ in an autoclave at $121^{\circ} \mathrm{C}$ for $20 \mathrm{~min}$, then the preparation was washed with deionized water for 5 min. Endogenous peroxidase was blocked by using hydrogen peroxide in $3 \%$ methanol for $30 \mathrm{~min}$ at room temperature. After that, it was washed with Tris Buffer Citrate (TBS) for 5 min, followed by blocking nonspecific protein with Background Sniper Universal for $15 \mathrm{~min}$, and then washed again with TBS. After the blocking process, the preparations were incubated with the primary mouse monoclonal antibody Foxp3 (236A/E7, ab20034 Abcam) with a dilution of 1:200 and stained. It was evaluated under light microscopy on well-stained areas. The tumor and stroma areas were well-stained with a $200 x$ magnification. Furthermore, calculations were carried

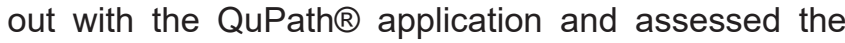
percentage of Foxp3 expression in 5-10 visual fields in the intratumoral and peritumoral areas. Foxp3 positivity staining is seen in the nucleus.

Two groups were formed depending on the number of cells stained that is $<20 \%$ and $>20 \%$. Low TILs if intratumoral and peritumoral stained lymphocyte cells were $<20 \%$, while high TILs if intratumoral and peritumoral stained lymphocyte cells were $>20 \%$. The immunohistochemical scoring system used was the one used by the Petersen et al. and Kara et al. [1], [7].

The percentage of intratumoral Foxp3 was obtained from the comparison between the number of lymphocyte cells stained positively with Foxp3 divided by the total number of total lymphocyte cells (stained and unstained) intratumoral, while the percentage of peritumoral Foxp3 was obtained from the comparison between the number of lymphocyte cells stained positively with Foxp3 divided by peritumoral total lymphocyte count. The total Foxp3 expression was the average of total accumulation intratumoral Foxp3 and peritumoral Foxp3.

Data were collected and then analyzed using the SPSS 20.0 statistical application. Statistical test using cross tab table, then used statistical analysis using Chi-square test. The results were stated to be statistically significant if the $p<0.05$ with a $95 \%$ confidence interval.

Table 1: Patient characteristics

\begin{tabular}{lll}
\hline Variable & Frequency $(\mathrm{n})$ & Percentage \\
\hline Gender & & \\
Male & 40 & 66.7 \\
Female & 20 & 33.3 \\
Age group & 2 & \\
10-19 years old & 5 & 3.3 \\
$20-29$ years old & 9 & 8.3 \\
30-39 years old & 18 & 15 \\
40-49 years old & 15 & 30 \\
50-59 years old & 11 & 25 \\
>60 years old & & 18.3 \\
Stage & 1 & 1.7 \\
Stage II & 19 & 31.7 \\
Stage III & 13 & 21.7 \\
Stage IVA & 20 & 33.3 \\
Stage IVB & 7 & 11.7 \\
Stage IVC & & \\
\hline
\end{tabular}

\section{Results}

In this study, there were 60 cases with paraffin block and complete clinical data and met the inclusion criteria. A total of 40 cases $(66.7 \%)$ were male and 20 cases $(33.3 \%)$ were female with a ratio of $2: 1$. The age range of most cases was at the age of 40-49 years, with the youngest age being 11 years old and the oldest being 71 years old. The most cases were diagnosed at clinical stage IVB 20 cases (33.3\%) (Table 1). 
Histopathological characteristics assessed were differentiation, growth pattern, intratumoral and peritumoral lymphocyte infiltration, and lymphovascular invasion. Foxp3 staining using a positive immunohistochemical method stained with brown in the nucleus of lymphocyte cells (Figure 1). The distribution of histopathological characteristics in this study can be seen in Table 2 .

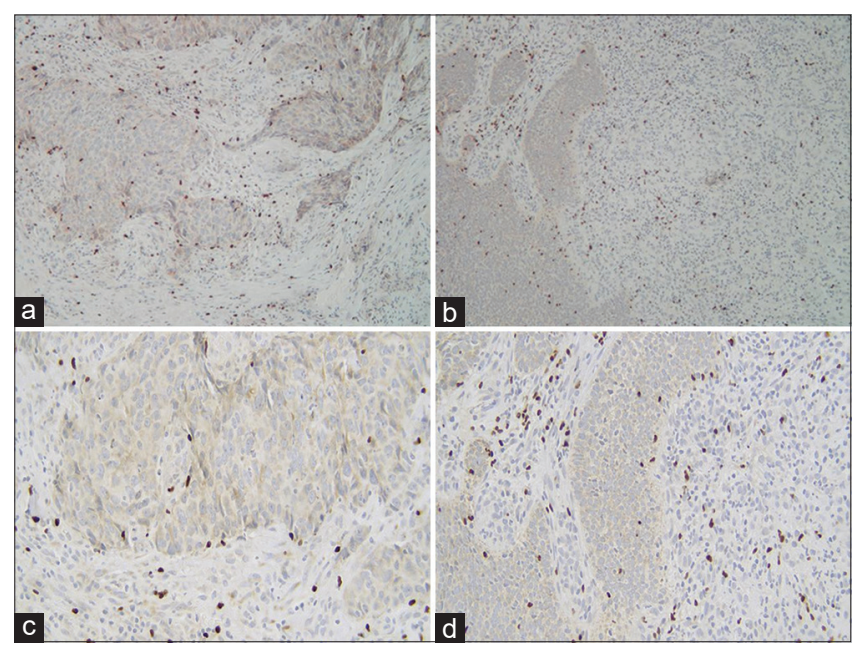

Figure 1: Foxp3 staining. Foxp3 immunohistochemical stains were stained in the nucleus of intratumoral and peritumoral lymphocytes. (a and b 200x objective magnification; $c$ and $d 400 \times$ objective magnification)

Table 3 shows the relationship between Foxp3 expression in non-keratinizing NPC and postchemoradiation therapy response.

Table 2: Histopathological characteristics

\begin{tabular}{|c|c|c|}
\hline Variable & Frequency $(\mathrm{n})$ & Percentage \\
\hline \multicolumn{3}{|l|}{ Differentiation } \\
\hline Differentiated & 10 & 16.7 \\
\hline Undifferentiated & 50 & 83.3 \\
\hline \multicolumn{3}{|l|}{ Growth pattern } \\
\hline Solid & 23 & 38.3 \\
\hline Infiltrative & 37 & 61.7 \\
\hline \multicolumn{3}{|c|}{ Intratumoral lymphocyte } \\
\hline Mild & 27 & 45 \\
\hline \multicolumn{3}{|l|}{ Infiltration } \\
\hline Moderate & 27 & 45 \\
\hline Severe & 6 & 10 \\
\hline \multicolumn{3}{|c|}{ Peritumoral lymphocyte } \\
\hline Mild & 16 & 26.7 \\
\hline \multicolumn{3}{|l|}{ Infiltration } \\
\hline Moderate & 34 & 56.7 \\
\hline Severe & 10 & 16.6 \\
\hline \multicolumn{3}{|c|}{ Lymphovascular invasion } \\
\hline No invasion & 57 & 95 \\
\hline Invasion & 3 & 5 \\
\hline
\end{tabular}

There was a significant difference between intratumoral Foxp3 expression and total Foxp3 expression on response to therapy with $p=0.01$ and 0.001 , respectively. There was no significant difference between peritumoral Foxp3 expression and therapy response in this study.

Table 3: Foxp3 expression with post-chemoradiation therapy response

\begin{tabular}{lccc}
\hline Variable & \multicolumn{2}{c}{ Therapy response } & p \\
\cline { 2 - 3 } & Response & No response & \\
\hline Foxp3 expression (intratumoral) & 20 & 10 & \multirow{2}{*}{0.01} \\
Low & 10 & 20 & \\
High & 21 & 15 & 0.114 \\
Foxp3 expression (peritumoral) & 9 & 15 & \\
Low & & & \\
High & 23 & 10 & 0.001 \\
Foxp3 expression (total) & 7 & 20 & \\
Low & & & \\
High & &
\end{tabular}

Table 4 shows demographic data in the form of gender, age group and clinical stage and Foxp3 expression. There was no statistically significant relationship between gender, age group, and clinical stage.

Table 4: Foxp3 expression with patients characteristics

\begin{tabular}{|c|c|c|c|c|c|c|c|c|c|}
\hline \multirow[t]{2}{*}{ Variable } & \multicolumn{3}{|c|}{$\begin{array}{l}\text { Foxp3 expression } \\
\text { intratumoral }\end{array}$} & \multicolumn{3}{|c|}{$\begin{array}{l}\text { Foxp3 expression } \\
\text { peritumoral }\end{array}$} & \multicolumn{3}{|c|}{$\begin{array}{l}\text { Foxp3 expression } \\
\text { total }\end{array}$} \\
\hline & Low & High & $\mathrm{p}$ & Low & High & $\mathrm{P}$ & Low & High & $\mathrm{p}$ \\
\hline \multicolumn{10}{|l|}{ Gender } \\
\hline Male & 20 & 20 & 1.000 & 25 & 15 & 0.576 & 22 & 18 & 1.000 \\
\hline Female & 10 & 10 & & 11 & 9 & & 11 & 9 & \\
\hline \multicolumn{10}{|l|}{ Age group } \\
\hline $10-19$ years old & 1 & 1 & 0.854 & 0 & 2 & 0.576 & 1 & 1 & 0.812 \\
\hline $20-29$ years old & 2 & 3 & & 4 & 1 & & 3 & 2 & \\
\hline $30-39$ years old & 5 & 4 & & 4 & 5 & & 6 & 3 & \\
\hline $40-49$ years old & 11 & 7 & & 13 & 5 & & 11 & 7 & \\
\hline $50-59$ years old & 7 & 8 & & 9 & 6 & & 8 & 7 & \\
\hline$>60$ years old & 4 & 7 & & 6 & 5 & & 4 & 7 & \\
\hline \multicolumn{10}{|l|}{ Stage } \\
\hline II & 1 & 0 & 0.646 & 1 & 0 & 0.735 & 1 & 0 & 0.812 \\
\hline III & 9 & 10 & & 8 & 11 & & 9 & 9 & \\
\hline IVA & 7 & 6 & & 9 & 4 & & 8 & 8 & \\
\hline IVB & 11 & 9 & & 15 & 5 & & 12 & 12 & \\
\hline IVC & 2 & 5 & & 3 & 4 & & 3 & 3 & \\
\hline
\end{tabular}

Foxp3 expression data with histopathological characteristics are listed in Table 5. Characteristics of differentiation, growth pattern, and lymphovascular invasion did not show a statistically significant relationship. There is a significant relationship between lymphocyte infiltration characteristics and Foxp3 expression. Intratumoral and peritumoral lymphocyte infiltration was found to be directly proportional to Foxp3 expression. Mild lymphocytic infiltration, both intratumoral and peritumoral, was found to be more in the group with low Foxp3, on the contrary, the amount of lymphocyte infiltration was significantly higher in the group with high Foxp3.

Table 5: Expression of Foxp3 with histopathological characteristics

\begin{tabular}{|c|c|c|c|c|c|c|c|c|c|}
\hline \multirow[t]{2}{*}{ Variable } & \multicolumn{3}{|c|}{$\begin{array}{l}\text { Foxp3 expression } \\
\text { intratumoral }\end{array}$} & \multicolumn{3}{|c|}{$\begin{array}{l}\text { Foxp3 expression } \\
\text { peritumoral }\end{array}$} & \multicolumn{3}{|c|}{$\begin{array}{l}\text { Foxp3 expression } \\
\text { total }\end{array}$} \\
\hline & Low & High & $\mathrm{p}$ & Low & High & $\mathrm{p}$ & Low & High & $\mathrm{p}$ \\
\hline \multicolumn{10}{|l|}{ Differentiation } \\
\hline Differentiated & 6 & 4 & \multirow[t]{2}{*}{0.488} & 6 & 4 & \multirow[t]{2}{*}{1.000} & 7 & 3 & \multirow[t]{2}{*}{0.296} \\
\hline Undifferentiated & 24 & 26 & & 30 & 20 & & 26 & 24 & \\
\hline \multicolumn{10}{|l|}{ Growth Pattern } \\
\hline Solid & 14 & 9 & \multirow[t]{2}{*}{0.184} & 16 & 7 & \multirow[t]{2}{*}{0.233} & 16 & 7 & \multirow[t]{2}{*}{0.074} \\
\hline Infiltrative & 16 & 21 & & 20 & 17 & & 17 & 20 & \\
\hline \multicolumn{10}{|c|}{ Intratumoral lymphocyte } \\
\hline \multicolumn{10}{|c|}{ infiltration } \\
\hline Mild & 23 & 4 & \multirow[t]{3}{*}{0.000} & 22 & 5 & \multirow[t]{3}{*}{0.002} & 23 & 4 & \multirow[t]{3}{*}{0.000} \\
\hline Moderate & 6 & 21 & & 11 & 16 & & 7 & 20 & \\
\hline Severe & 1 & 5 & & 3 & 3 & & 3 & 3 & \\
\hline \multicolumn{10}{|c|}{ Peritumoral lymphocyte } \\
\hline Mild & 15 & 1 & \multirow[t]{3}{*}{0.000} & 14 & 2 & \multirow[t]{3}{*}{0.009} & 15 & 1 & \multirow[t]{3}{*}{0.000} \\
\hline Moderate & 11 & 23 & & 18 & 16 & & 14 & 20 & \\
\hline Severe & 4 & 6 & & 4 & 6 & & 4 & 6 & \\
\hline \multicolumn{10}{|c|}{ Lymphovascular invasion } \\
\hline No invasion & 28 & 29 & \multirow[t]{2}{*}{0.554} & 33 & 24 & \multirow[t]{2}{*}{0.147} & 30 & 27 & \multirow[t]{2}{*}{0.108} \\
\hline Invasion & 2 & 1 & & 3 & 0 & & 3 & 0 & \\
\hline
\end{tabular}

Table 6 shows the association of histopathological characteristics with the therapy response. There was a significant relationship between growth pattern $(p=0.001)$ and intratumoral lymphocyte infiltration $(p=0.004)$ with therapy response. There was no significant relationship between differentiation, peritumoral lymphocyte infiltration, and lymphovascular invasion with therapy response. Infiltrative tumor growth patterns ( 25 cases) were more common in the unresponsive group, while solid growth patterns 
Table 6: Histopathological characteristics with therapy response

\begin{tabular}{|c|c|c|c|}
\hline \multirow[t]{2}{*}{ Variable } & \multicolumn{2}{|c|}{ Therapy response } & \multirow[t]{2}{*}{$\mathrm{p}$} \\
\hline & Response & No response & \\
\hline \multicolumn{4}{|l|}{ Differentiation } \\
\hline Differentiated & 5 & 5 & \multirow[t]{2}{*}{1.000} \\
\hline Undifferentiated & 35 & 25 & \\
\hline \multicolumn{4}{|l|}{ Growth pattern } \\
\hline Solid & 18 & 5 & \multirow[t]{2}{*}{0.001} \\
\hline Infiltrative & 12 & 25 & \\
\hline \multicolumn{4}{|c|}{ Intratumoral lymphocyte } \\
\hline Mild & 19 & 8 & \multirow[t]{4}{*}{0.004} \\
\hline \multicolumn{3}{|l|}{ Infiltration } & \\
\hline Moderate & 6 & 21 & \\
\hline Severe & 5 & 1 & \\
\hline \multicolumn{4}{|c|}{ Peritumoral lymphocyte } \\
\hline Mild & 8 & 8 & \multirow[t]{4}{*}{0.097} \\
\hline \multicolumn{3}{|l|}{ Infiltration } & \\
\hline Moderate & 14 & 20 & \\
\hline Severe & 8 & 2 & \\
\hline \multicolumn{4}{|c|}{ Lymphovascular invasion } \\
\hline No invasion & 29 & 28 & \multirow[t]{2}{*}{0.554} \\
\hline Invasion & 1 & 2 & \\
\hline
\end{tabular}

(18 cases) were more common in the chemoradiation response group. Intratumoral lymphocyte infiltration gave significant results in the presence of moderate lymphocyte infiltration which was more commonly found in the unresponsive group, and mild lymphocyte infiltration which was more commonly found in the response group.

\section{Discussion}

NPC has been known since 1845 but until now this disease is still a problem and it is the most common primary tumor in men in Indonesia. Various factors ranging from clinical to histopathological are used as predictive factors for therapy in NPC. Foxp3 immunohistochemistry was performed as a marker to see the presence of Treg lymphocyte cells in the tumor environment in NPC, especially the non-keratinized type. Foxp3 is known to inhibit the activity of CD4 and CD8 which play a role in eliminating tumor cells.

Demographic data from various literatures state that NPC is found more in old age and in male sex. The same situation was also found in this study. The age range was mostly found in the 40-49 year age group with a mean age of 45 years and the percentage of men was $72.2 \%$ compared to $27.8 \%$ for women.

One of the causes of delays in establishing the diagnosis and treatment of NPC is patients who are late for treatment, thus delaying the diagnosis. The results of clinical data, it was found that as many as 20 cases $(33.3 \%)$ came already diagnosed at stage IVB. This situation caused a significant decrease in life expectancy. In the study of Kara et al. [7] it was stated that the cause of patients being late for treatment was due to the variety of symptoms and usually asymptomatic at an early stage. Although patients with early stages have a good response to chemoradiation, recurrence and metastases can also be found at an early stage with a prevalence of $6-11 \%$ and metastases were often found in the bone, lung, liver, and lymph nodes [7]. In this study, there were seven patients with metastases $(11.7 \%)$ and the most common were bone metastases.

An assessment has been made on preparations using Foxp3 associated with chemoradiation response. There were significant differences in Foxp3 expression in the response group compared to the unresponsive group. Among the unresponsive group of cases, 4 of them showed distant (bone) metastases. It has been reported in several studies that increased Foxp3 expression is associated with poor prognosis. In this study, the expression of intratumoral Foxp3 ranged from $3.2 \%$ to $40.8 \%$ and peritumoral Foxp3 ranged from $2.6 \%$ to $26.6 \%$.

In a study conducted by Lau et al. [22] it was found that an increase in CD4, CD25, and Foxp3 in the blood in 57 patients with NPC compared to the control group and obtained as many as 5 patients had an increase in Foxp3 in their tumor tissue. Although the patient group and the control group had almost the same CD8 and CD4 counts, this study found a tendency to decrease the number of CD4 and CD8 cells. The increase in the number of Foxp3 is one of the causes of the decrease in the number of CD4 and CD8 so that the role of CD4 and CD8 to eliminate tumor cells is reduced. The increase in Foxp3 expression in this study was also not associated with stage, tumor size, lymph node metastases, and distant metastases. In a study conducted by Zang et al. [9] it was found that Foxp3 can be used as a prognostic factor in NPC patients, especially in advanced-stage patients, but there was no relationship between Foxp3 and tumor size.

Yoshioka et al. [23] on esophageal SCC patients showed that the life expectancy of patients with low Foxp3 expression was better than patients with high Foxp3 expression. Research Weller et al. [24] reported that low life expectancy in patients with carcinoma of the larynx, hypopharynx, and oropharynx was found in patients with high expression of Foxp3 and Cox-2. In another study, Sun et al. [25] found an association between increased Foxp3 with tumor stage and lymph node metastases in patients with head and neck carcinoma (oral cavity, nasopharynx, oropharynx, hypopharynx, and larynx). In addition, the study of Sun et al. [25] also reported an increase in Foxp3 associated with tumor progression.

In this study, there was no significant relationship between peritumoral Foxp3 expression and response to therapy. Similar results were obtained in Kara et al. [7] study of 60 NPC patients who had undergone chemoradiation. A total of 28 patients who responded to chemoradiation showed low peritumoral Foxp3 expression, but in the unresponsive group, three patients with low peritumoral Foxp3 expression were also found.

A significant relationship was found between intratumoral Foxp3 expression and response to therapy 
( $p=0.01)$. High Foxp3 expression was found more in the unresponsive group (20 cases) and ten cases in the response group. In addition, this study showed significant results between total Foxp3 expression and response to therapy. There were 23 cases in the low Foxp3 expressing response group and seven cases in the high Foxp3 expression group. From these data, it was found that in the unresponsive group, Foxp3 expression was found to be higher than the response group. Almangush et al. [26] reported that intratumoral TIL was associated with overall survival (OS) and disease-specific survival. Although intratumoral and peritumoral TIL were reported to have an association with prognosis, a significant association was found only in intratumoral TIL as found in the study of James et al. [27] in patients with ovarian carcinoma. Several studies also recommend conducting TIL assessments in NPC patients that focus on the intratumoral rather than peritumoral areas because of the involvement of the nasopharynx as an organ with a large number of lymphoid stromal components, which creates difficulties and overlaps in the assessment of peritumoral TIL. Why peritumoral Foxp3 expression in this study did not provide significant results.

The relationship between Foxp3 expression and histopathological characteristics was also assessed in this study. Tumor differentiation, growth pattern, and lymphovascular invasion did not show a statistically significant relationship. The results that did not show a significant relationship were partly due to the histomorphological of the tumor in almost all cases that tended to be homogeneous. Then in the latest WHO classification in 2016, the prognostic differences in histologic types are only based on keratin and nonkeratinized types. There is no prognostic difference in the non-keratinizing type based on the degree of differentiation [1].

In this study, a statistically significant relationship was obtained in lymphocyte infiltration with Foxp3 expression both intratumoral and peritumoral. Significant lymphocyte infiltration was followed by a high increase in Foxp3 expression, whereas a mild lymphocytic infiltration was followed by a low Foxp3 expression. These results are in line with the results of research conducted by Almangush et al. [26] with patients in non-endemic countries with NPC and Wang et al. [29] with patients in NPC endemic countries. An increase in the ratio of Foxp3 to CD4 and CD8 was also obtained in the study of Tang et al. [30] in patients with pancreatic ductal adenocarcinoma who explained that tumor tissue infiltrated by lymphocytes showed increased Foxp3, CD4, and CD8 expression compared to normal pancreatic tissue as a control group. As the role of lymphocytes as cells that mediate inflammation to eliminate tumor cells and followed by an increase in the expression of CD4, CD8, and Foxp3 Treg cells in the tumor environment, the increased expression of CD4, CD8, and Foxp3 can be directly proportional to the increase in lymphocyte infiltration in the tumor area. The matter of homeostasis of immune and inflammatory responses and the percentage proportion of each cell in the tumor area can still be studied further. Although there is still debate about the role of lymphocytes in tumor cells, Zhang et al. [9] stated that NPC with tumor cells infiltrated by lymphocytes actually has a better prognosis. This is not in line with the hypothesis proposed by Gooden et al. [31]

In several other studies reported increased life expectancy associated with high TIL. However, the exact cause of TIL that affects the prognosis has not been fully elucidated. The presence of TIL may explain the mechanism of tumor cell elimination required in the tumor environment. Tumor progression that is inhibited through high TIL has also been reported, so that the mechanism of increasing TIL has an impact on the effectiveness of increasing the elimination activity of tumor cells which also has an impact on good life expectancy [29]. Wang et al. [29] reported that higher intratumoral and peritumoral TIL counts were associated with a better prognosis (OS and DFS). Reported in that study, intratumoral and peritumoral TIL were independent prognostic factors in NPC.

In this study, histopathological characteristics and their relationship to response to therapy were analyzed. Significant results were found in the characteristics of the tumor growth pattern and intratumoral lymphocyte infiltration. Infiltrative growth patterns were more common in the unresponsive group, while solid growth patterns were more common in the response group. NPC is known to be a highly infiltrative tumor type with a tendency to spread to surrounding soft tissue structures, causing a larger tumor area. In some studies, the size and volume of the primary tumor are important prognostic factors in the success of therapy. Fletcher in his research obtained data that tumor volume can be an indication of the number of tumor cells that should decrease after therapy. NPC patients who receive chemoradiation with large tumor sizes have a significant impact on increasing the risk of hypoxic areas so that they are resistant to radiation therapy [32]. Intratumoral lymphocyte infiltration in this study gave significant results on the response to therapy. Higher lymphocyte infiltration was found in the unresponsive group than in the response group. It has been described in the literature that cytotoxic CD8+ cells are the most sensitive subpopulation to radiationinduced apoptosis, whereas Treg cells are more resistant to radiation than other lymphocyte subpopulations [12]. In this study, high intratumoral lymphocyte infiltration also expressed higher intratumoral than peritumoral Foxp3 expression. Foxp3 in high amounts will suppress the function of CD8+ and CD4+ cells so that it has a negative impact on the therapeutic response caused. Peritumoral lymphocyte infiltration in this study did not provide statistically significant results on the response to therapy and is in line with the results of 
research conducted by Kara et al. [7] In the study Luo et al. [33] who analyzed normal nasopharyngeal tissue with tissue of NPC patients, found differences in immune cell profiles in normal nasopharyngeal tissue and NPC based on genetic expression in NPC which resulted in an increase in the number of macrophages and a decrease in CD4 cells and memory B cells that were associated with NPC tumorigenesis. Increased numbers of TIL immune cell profiles including T cells, macrophages, dendritic cells, and mast cells have been reported to provide significant prognostic value in NPC.

Apart from the anatomical factor of the nasopharynx which is basically an organ with many lymphoid aggregates so that it can give varying results, the exploration of genetic involvement and other immune cell infiltration in the area of NPC tumors needs to be investigated further. Another thing is that there is no cutoff yet standard used for TIL reporting on NPC.

\section{Conclusion}

Foxp3 expression had a statistically significant relationship with the response to NPC therapy.

\section{Acknowledgment}

We express our gratitude to Universitas Indonesia who funded this research through Hibah PITTA and Cipto Mangunkusumo Hospital's medical record who provided data for this research.

\section{References}

1. Petersson BF, Bell D, El-Mofty SK, Gillison M, Lewis JS, Nadal A, et al. Nasopharyngeal carcinoma. In: El-Naggar AK, Chan JK, Grandis JR, Takata T, Slootweg PJ, editors. WHO Classification of Head and Neck Tumours. Lyon: IARC; 2016. p. 64-70.

2. Wei KR, Zheng RS, Zhang SW, Liang ZH, Qu ZX, Chen QW. Naropharyngeal carcinoma incidence and mortality in Tiongkok in 2010. Chin J Cancer. 2014;33:381-7. https://doi.org/10.5732/ cjc. 014.10086 PMid:25096544

3. Adham M, Kurniawan A, Muhtadi A, Roezin A, Hermani B, Gondhowiardjo S, et al. Nasopharyngeal carcinoma in Indonesia: Epidemiology, incidence, signs, and symptoms at presentation. Chin J Cancer. 2012;31(4):186-96. https://doi. org/10.5732/cjc.011.10328 PMid:22313595

4. Badan Registrasi Kanker Perhimpunan Dokter Spesialis Patologi Indonesia. Kanker di INDONESIA Tahun 2015: Data
Histopatologik, Jakarta; 2017.

5. Panduan Nasional Penanganan Kanker Nasofaring. Komite Nasional Penganggulangan Kanker. Jakarta: Kementerian kesehatan republik Indonesia; 2017.

6. Wondergem NE, Nauta IH, Muijlwijk $T$, Leemans $C R$, van de ven $R$. The immune microenvironment in head and neck squamous cell carcinoma: On subsets and subsites. Curr Oncol Rep. 2020;81:1-14.

7. Kara I, Cagli S, Vural A, Yuce I, Gundog M, Deniz K, et al. The effect of FoxP3 on tumour stage, treatment response, recurrence and survivalability in nasopharynx cancer patients. Clin Otolaryngol. 2019;44(3):349-55. https://doi.org/10.1111/ coa. 13311

PMid:30756505

8. Ooft M, Ipenburg JA, Sanders ME, Kranendonk M, Hofland I, Bree $R$, et al. Prognostic role of tumour-associated macrophages and regulatory $\mathrm{T}$ cells in EBV-positive and EBV- negative nasopharyngeal carcinoma. J Clin Pathol. 2017;71(3):267-274. https://doi.org/10.1136/jclinpath-2017-204664

PMid:28877959

9. Zhang YL, Li J, Mo HY, Qiu F, Zheng LM, Qian CN, et al. Different subsets of tumor infiltrating lymphocytes correlate with NPC progression in different ways. Mol Cancer. 2010;9:4 https://doi.org/10.1186/1476-4598-9-4

PMid:20064222

10. Wu Y, Borde M, Heissmeyer V. FOXP3 controls regulatory $T$ cell function through cooperation with NFAT. Cell. 2006;126(2):375-87. https://doi.org/10.1016/j.cell.2006.05.042 PMid:16873067

11. Cools N, Ponsaerts $P$, van Tendeloo VF, Berneman ZN Regulatory $\mathrm{T}$ cells and human disease. Clin Dev Immunol. 2007;2007:89195. https://doi.org/10.1155/2007/89195 PMid: 18317534

12. Shinto $E$, Hase $K$, Hashiguchi $Y$, Sekizawa $A$, Ueno $H$, Shikina A, et al. CD8+ and Foxp3+ tumor infiltrating T-cells before and after chemoradiotherapy for rectal cancer. Ann Surg Oncol. 2014;21 Suppl 3:S414-21. https://doi.org/10.1245/ s10434-014-3584-y PMid:24566864

13. Chan JK. Virus-associated neoplasm of the nasopharynx and sinonasal tract: diagnostic problems. Mod Pathol. 2017;30(S1):568-83. https://doi.org/10.1038/ modpathol.2016.189

PMid:28060369

14. Eisenhauer EA, Therasse $P$, Bogaerts J, Schwartz LH, Sargent D, Dancet J, et al. New response evaluation criteria in solid tumours: Revised RECIST guideline (version 1.1). Eur J Cancer.2009;45(2):228-47. https://doi.org/10.1016/j. ejca.2008.10.026

PMid: 19097774

15. Li J, Mo HY, Xiong G, Zhang L, He J, Huang ZF, et al. Tumor microenvironment macrophage inhibitory factor directs the accumulation of interleukin-17-producing tumor infiltrating lymphocytes and predicts favorable survival in nasopharyngeal carcinoma patients. J Biol Chem. 2012;287(42):35484-95. https://doi.org/10.1074/jbc.M112.367532 PMid:22893706

16. Vasilescu F, Arsene D, Cionca F, Comanescu M, Enache V, losif $\mathrm{C}$, et al. FoxP3 and IL17 expression in tumor infiltrating lymphocytes (TIL) and tumor cells-correlated or independent factors? Rom J Morphol Embryol. 2013:54(1):43-39. PMid:23529308

17. Pereira LM, Gomes ST, Ishak R, Callinoto AC. Regulatory $\mathrm{T}$ cell and forkhead box protein 3 as modulators of immune homeostasis. Front Immunol. 2017;8:605. https://doi. 
org/10.3389/fimmu.2017.00605

PMid:28603524

18. Lee RG. Phenotypic and functional properties of tumor-infiltrating regulatory T cells. Mediators Inflamm. 2017;2017:5458178. https://doi.org/10.1155/2017/5458178.

PMid:29463952

19. Abbas AK, Lichtman AH, Pillai S. Cellular and Molecular Immunology. 9th ed. Philadelphia, PA: Saunders Elsevier; 2018.

20. Li C, Jiang P, Wei S, Xu X, Wang J. Regulatory T cells in tumor microenvironment: New mechanisms, potential therapeutic strategies and future prospects. Mol Cancer. 2020;19(1):116. https://doi.org/10.1186/s12943-020-01234-1

PMid:32680511

21. Xu L, Wang C, Wen Z, Zhou Y, Liu Z, Lian Y, et al. CpG oligodeoxynucleotides enhance the efficacy of adoptive cell transfer using tumor infiltrating lymphocytes by modifying the Th1 polarization and local infiltration of Th17 cells. Clin Dev Immunol. 2010;2010:410893. https://doi.org/10.1155/2010/410893 PMid:2098127

22. Lau K, Cheng S, Lo K. Increase in circulating Foxp3+ CD4+ CD25 high regulatory $T$ cells in nasopharyngeal carcinoma patients. $\mathrm{Br} \mathrm{J}$ Cancer. 2007;96(4):617-22. https://doi. org/10.1038/sj.bjc.6603580

PMid:17262084

23. Yoshioka T, Miyamoto M, Cho $\mathrm{Y}$, Ishikawa $\mathrm{K}$, Tsuchikawa $\mathrm{T}$, Kadoya $\mathrm{M}$, et al. Infiltrating regulatory $\mathrm{T}$ cell numbers is not a factor to predict patient's survival in oesophageal squamous cell carcinoma. Br J Cancer. 2008;98(7):1258-63. https://doi. org/10.1038/sj.bjc.6604294

PMid:18349839

24. Weller P, Bankfalvi A, Gu X, Dominas N, Lehnerdt GF, Zeidler $\mathrm{R}$, et al. The role of tumour FoxP3 as prognostic marker in different subtypes of head and neck cancer. Eur J Cancer. 2014;50(7):1291-300. https://doi.org/10.1016/j. ejca.2014.02.016 PMid:24630394

25. Sun W, Li WJ, Wu CY, Zhong H, Wen WP. CD45RA-Foxp3 high but not CD45RA+ Foxp3 low suppressive $T$ regulatory cells increased in the peripheral circulation of patients with head and neck squamous cell carcinoma and correlated with tumor progression. J Clin Cancer Res. 2014;33(1):35. https://doi. org/10.1186/1756-9966-33-35

PMid:24761979

26. Almangush A, Ruuskanen M, Hagstrom J, Hirvikoski $P$, Tommola S, Kosma V, et al. Tumor infiltrating lymphocytes associate with outcome in nonendemic nasopharyngeal carcinoma: A multicenter study. Hum Pathol. 2018;81:211-9. https://doi.org/10.1016/j.humpath.2018.07.009

\section{PMid:30030117}

27. James FR, Jiminiz M, Alsop J. Association between tumour infiltrating lymphocytes, hystotype and clinical outcome in epithelial ovarian cancer. BMC Cancer. 2017;17(1):657. https:// doi.org/10.1186/s12885-017-3585-x

PMid:28931370

28. Hendy S, Salgado R, Gevaert T. Assessing tumor-infiltrating lymphocytes in solid tumors: A practical review for pathologists and proposal for a standardized method from the international immuno-oncology biomarkers working group: Part 2: TILs in melanoma, gastrointestinal tract carcinoma, non-small cell lung carcinoma and mesothelioma, endometrial and ovarian carcinomas, squamous cell carcinoma of the head and neck, genitourinary carcinomas, and primary brain tumors. Adv Anat Pathol. 2017;24(6):311-35. https://doi.org/10.1097/ PAP. 0000000000000161

PMid:28777143

29. Wang $Y$, Chen YP, Zhang $Y$, Jiang W, Liu N, Yun JP, Sun Y, et al. Prognostic significance of tumor-infiltrating lymphocytes in nondisseminated nasopharyngeal carcinoma: A large-scale cohort study. Int J Cancer. 2018;142(12):2558-66. https://doi. org/10.1002/ijc.31279

PMid:29377121

30. Tang $\mathrm{T}, \mathrm{Xu} \mathrm{X}$, Guo S, Zhang $\mathrm{C}$, Tang $\mathrm{Y}$, Tian $\mathrm{Y}$, et al. An increased abundance of tumor-infiltrating regulatory $T$ cells is correlated with the progression and prognosis of pancreatic ductal adenocarcinoma. PLoS One. 2014:9(3):e91551. https:// doi.org/10.1371/journal.pone.0091551

PMid:24637664

31. Gooden MH, Bock GH, Leffers N, Daemen T, Nijman HW. The prognostic influence of tumour infiltrating lymphocytes in cancer: A systematic review with meta-analysis. $\mathrm{Br} \mathrm{J}$ Cancer 2011;105(1):93-103. https://doi.org/10.1038/bjc.2011.189 PMid:21629244

32. Feng $\mathrm{M}$. Tumor volume is an independent prognostic indicator of local control in nasopharyngeal carcinoma patients treated with intensity-modulated radiotherapy. Radiat Oncol. 2013;8:208. https://doi.org/10.1186/1748-717X-8-208

PMid:24007375

33. Luo, Si M, Jiang G, Liu, Xinzi B. Immune infiltration in nasopharyngeal carcinoma based on gene expression. Medicine (Baltimore). 2019;98(39):e17311. https://doi.org/10.1097/ MD. 0000000000017311

PMid:31574860

Author Query???

AQ7: Kindly cite reference $13-21$ and 28 in the text part and also cite in chronologically. 